\title{
Effect of Organic and Inorganic Fertilizers on Proximate Analysis of Rhodes Grass (Chloris gayana L. Knuth.)
}

\author{
Ahmed M. Yossif, Yassin M. Ibrahim* \\ Agronomy Department, Faculty of Agricultural Studies, Sudan University of Science and Technology, Khartoum, Shambat, Sudan \\ *Corresponding Author: dagash501@yahoo.com
}

Copyright (C 2013 Horizon Research Publishing All rights reserved.

\begin{abstract}
Abtract A field experiment was conducted during (2009/2010) season in Demonstration Farm of the Faculty of Agricultural Studies, Sudan University of Science and Technology at Shambat, Sudan. The objective was to study the effect of fertilizers (urea, farmyard and chicken manure) on nutritive value of Rhodes grass. The fertilizer treatments used in this study were urea [U $(100 \mathrm{KgN} / \mathrm{ha})]$, farmyard manure [FYM (5ton/ha)], chicken manure [ CHM (3ton/ha)], combinations between them (U+FYM, U+CHM, $\mathrm{FYM}+\mathrm{CHM}$, and U+FTM+CHM) with 8 cuts (Two monthes firstly and monthly after that to $8^{\text {th }}$ cut). The experiment was arranged in Randomized Complete Block Design (RCBD) with three replicates. The results revealed that all proximate analysis parameters were not significantly affected by fertilizers.
\end{abstract}

Keywords Rhodes Grass; Fertilizers; Organic; Inorganic; Sudan

\section{Introduction}

Forage production is gaining more attention in the tropics and subtropics; in both developed and developing countries. New species, varieties and cultivars of forage and pasture plant have been introduced from areas and countries rich in forage and pasture plant to areas where they are scare. In Sudan forage production is very important because the forage is basic source of energy for growth and maintenance and product increment of livestock. Additionally, it is important due to the fact that Sudan has a huge number of animals which is estimated to about 143 million heads in 1998 (63 m goats, $42 \mathrm{~m}$ sheep, $35 \mathrm{~m}$ cattle and $3 \mathrm{~m}$ camels) (Mohammed, 2000).

Rhodes grass (Chloris gayana L. Kunth.) is a summer-growing, stoloniferous perennial, whose runners provide good soils, from infertile sands to fertile brigalow clays. It is difficult to established and have persistent on heavy cracking clay soils. Rhodes grass is one of the best grasses for rotation land in tropical and subtropical areas, useful for establishment pasture leys. It is suitable for silage and hay liked by all kinds of stock but may causes skin trouble in horses. Its ability to establish rapidly makes it valuable for soil conservation (Reed, 1976).

Hassan (2002) reported that higher rate of chicken manure (7.5 tons/fed) significantly increased a number of growth attributes, $\mathrm{HCN}$ content, nutritive value and forage yield (fresh and dry) of two forage sorghum grass than the control. Adam (2004) observed that nitrogen improved forage quality by increasing crude protein of Teff grass. Others similar results were obtained by Eltelib (2004), Gasim (2001) and Soliman (2005). Moreover, Abbas (2003) and Gasim (2001) found that crude protein increased with increased phosphorus application. Gasim (2001) stated that increased in nitrogen level reduced fiber content of maize forage. Abbass (2003) showed that crude fiber decreased with addition of phosphorus. Kafats (1990) reported that nitrogen fertilization increased the crude protein of Rhodes grass by $15 \%$ at the early stage of growth. The main objective of this research is to evaluate the nutritive value of the forage as affected by different nitrogen sources.

\section{Material and Methods}

A field experiment was conducted during (2009/2010) season in Demonstration Farm of the Faculty of Agricultural Studies, Sudan University of Science and Technology at Shambat, Sudan, to study the effect of fertilizers (urea, farmyard and chicken manure) on nutritive value of Rhodes grass. The experimental site lies at latitude $15^{\circ} 40 \mathrm{~N}$, longitude $32^{\circ} 32^{\prime} \mathrm{E}$ and 280 meters above sea level. The climate of the locality is semi-desert (Adam, 1996). The soil is alkaline $(\mathrm{pH} 8.0)$, cracking clay with about $50 \%$ clay content. It contains about $0.065 \%$ nitrogen $(\mathrm{N}), 0.230 \mathrm{meq} / \mathrm{L}$ potassium $(\mathrm{K})$ and $0.193 \mathrm{meq} / \mathrm{L}$ available phosphorus $(\mathrm{P})$ as determined by El Basari (1999). The treatments composed of three fertilization treatments $100 \mathrm{~kg} \mathrm{~N} /$ ha as urea (U), 5ton/ha as farmyard manure (FYM), 3ton/ha as chicken manure 
(CHM) and combinations (U+FYM, U+CHM, FYM+CHM and $\mathrm{U}+\mathrm{FYM}+\mathrm{CHM}$ ) and no fertilizer as the control, in three replications. Treatments were arranged in a Randomize Complete Block Design (RCBD) with 8 cuts (The first cut was harvested after two mnothes and the others were mnothly.

The forage was sown on $1^{\text {st }}$ June 2009 to $1^{\text {st }}$ March 2010 and the fertilizer treatments were applied at sowing. The samples which were determined dry weight were completely dried by oven and plant samples were ground using an electrical grinder. Then Crude protein (CP\%), crude fiber $(\mathrm{CF} \%)$, ash\% according to Association of Official Agricultural Chemists "A.O.A.C." (1984), and Minerals (N, $\mathrm{P}, \mathrm{K}, \mathrm{Na}, \mathrm{Ca}$ and $\mathrm{Mg}$ ) were calculated. The data were statistically analyzed by Computer program (M STAT-C) (1989). Means separation was performed by using LSD (Least Significant Differance) procedure.

\section{Results and Discussion}

The results cleared that mean crude protein; crude fiber and ash content were not significantly affected by fertilizers (Table 1). These results agreed with Saad (2009) who reported that mean crude fiber was not significantly affected by nitrogen. The results showed that the best mean crude protein was obtained when three mixed fertilizers was used and the lowest mean crude fiber when mixing farmyard and chicken manure. Therefore, the best applied fertilizers was the mixture because more and more nitrogen and others minerals were incorporated. Nitrogen plays a great role in synthesis of protein. Also, phosphorus plays an important role in starch. Similar results regarding the increased crude protein due to the fertilizers application were obtained by several researchers. These results agreed with Brima (2007) who found exactly the same results. Also Adam (2004) observed that nitrogen improved forage quality by increasing crude protein of Teff grass. Others similar results were obtained by Eltelib (2004), Gasim (2001) and Soliman (2005). Moreover, Abbas (2003) and Gasim (2001) found that crude protein increased with increased phosphorus application. Gasim (2001) stated that increased in nitrogen level reduced fiber content of maize forage. Adam (2004) reported similar results on effect of nitrogen and Abbass (2003) showed that crude fiber decreased with addition of phosphorus. Results showed that mean crude protein in $1^{\text {st }}$ cut was better than $8^{\text {th }}$ cut. This is due to the fact that the $1^{\text {st }}$ was early stage of forage but the $8^{\text {th }}$ was late stage of forage. This is in agreement with Keftasa (1990) who reported that nitrogen fertilization increased the crude protein of Rhodes grass by $15 \%$ at the early stage of growth, but the percentage reduced at advanced growth stage. The results showed that mean minerals content $(\mathrm{N}, \mathrm{P}, \mathrm{K}, \mathrm{Na}, \mathrm{Ca}$ and $\mathrm{Mg}$ ) was not significantly affected by fertilizers (Table 2 and 3 ).

Table 1. The effect of different fertilizers on crude protien, crude fiber and ash content during $-2009 / 2010$

\begin{tabular}{|c|c|c|c|c|c|c|}
\hline \multirow{3}{*}{ Treatments } & \multicolumn{2}{|c|}{ Crude Protien } & \multicolumn{2}{|c|}{ Crude Fiber } & \multicolumn{2}{|c|}{ Ash content } \\
\hline & \multicolumn{2}{|c|}{ No. of Cuts } & \multicolumn{2}{|c|}{ No. of Cuts } & \multicolumn{2}{|c|}{ No. of Cuts } \\
\hline & 1 & 8 & 1 & 8 & 1 & 8 \\
\hline Urea (U) & 7.87 & 8.64 & 37.42 & 34.33 & 14.00 & 14.90 \\
\hline Farmyard Manure (FYM) & 10.80 & 6.83 & 37.99 & 35.64 & 11.50 & 14.63 \\
\hline Chicken Manure (CHM) & 8.70 & 7.36 & 32.73 & 35.73 & 14.00 & 14.52 \\
\hline $\mathrm{U}+\mathrm{FYM}$ & 10.61 & 7.11 & 34.05 & 34.95 & 15.10 & 14.43 \\
\hline $\mathrm{U}+\mathrm{CHM}$ & 11.75 & 6.48 & 30.67 & 36.16 & 15.20 & 14.63 \\
\hline $\mathrm{FYM}+\mathrm{CHM}$ & 10.45 & 5.11 & 29.32 & 35.95 & 15.10 & 14.35 \\
\hline $\mathrm{U}+\mathrm{FYM}+\mathrm{CHM}$ & 13.25 & 6.84 & 37.02 & 37.57 & 15.60 & 12.25 \\
\hline Control & 10.98 & 8.35 & 37.84 & 35.68 & 15.00 & 14.70 \\
\hline LSD $5 \%$ & 3.78 & 2.594 & 9.75 & 2.60 & 4.25 & 2.40 \\
\hline C.V & 20.45 & 20.89 & 34.63 & 4.15 & 16.82 & 9.57 \\
\hline $\mathrm{SE} \pm$ & 2.16 & 1.48 & 5.57 & 1.49 & 2.43 & 1.37 \\
\hline
\end{tabular}

$\mathrm{U}=$ Urea. $\mathrm{FYM}=$ Farmyard Manure. $\mathrm{CHM}=$ Chicken Manure. $\mathrm{LSD}=$ Least Significant Difference. $\mathrm{CV} \%=$ Coefficient of Variation. $\mathrm{SE} \pm=\mathrm{Standard}$ Error. 
Table 2. The effect of different fertilizers on nitrogen, phosphrous and potassium during -2009/2010

\begin{tabular}{|c|c|c|c|c|c|c|}
\hline \multirow{3}{*}{ Treatments } & \multicolumn{2}{|c|}{ Nitrogen } & \multicolumn{2}{|c|}{ Phosphrous } & \multicolumn{2}{|c|}{ Potassium } \\
\hline & \multicolumn{2}{|c|}{ No. of Cuts } & \multicolumn{2}{|c|}{ No. of Cuts } & \multicolumn{2}{|c|}{ No. of Cuts } \\
\hline & 1 & 8 & 1 & 8 & 1 & 8 \\
\hline Urea (U) & 1.251 & 1.372 & 3.12 & 3.63 & 18.86 & 10.27 \\
\hline Farmyard Manure (FYM) & 1.778 & 1.092 & 2.16 & 2.35 & 14.88 & 9.30 \\
\hline Chicken Manure (CHM) & 1.387 & 1.166 & 3.26 & 4.09 & 17.91 & 10.10 \\
\hline $\mathrm{U}+\mathrm{FYM}$ & 1.708 & 1.130 & 2.56 & 3.01 & 16.91 & 9.73 \\
\hline $\mathrm{U}+\mathrm{CHM}$ & 1.895 & 1.036 & 2.95 & 3.07 & 20.16 & 9.83 \\
\hline $\mathrm{FYM}+\mathrm{CHM}$ & 1.670 & 0.805 & 3.06 & 3.34 & 18.12 & 9.53 \\
\hline $\mathrm{U}+\mathrm{FYM}+\mathrm{CHM}$ & 2.119 & 1.092 & 2.61 & 3.10 & 17.67 & 10.17 \\
\hline Control & 1.783 & 1.335 & 2.84 & 2.95 & 17.70 & 10.47 \\
\hline LSD $5 \%$ & 0.640 & 0.413 & 0.84 & 1.37 & 2.19 & 1.37 \\
\hline C.V & 21.58 & 20.91 & 16.90 & 24.47 & 12.33 & 10.41 \\
\hline $\mathrm{SE} \pm$ & 0.366 & 0.237 & 0.48 & 0.78 & 3.84 & 1.81 \\
\hline
\end{tabular}

$\mathrm{U}=$ Urea. $\mathrm{FYM}=$ Farmyard Manure. $\mathrm{CHM}=$ Chicken Manure. $\mathrm{LSD}=$ Least Significant Difference. $\mathrm{CV} \%=$ Coefficient of Variation. $\mathrm{SE} \pm=\mathrm{Standard}$ Error

Table 3. The effect of different fertilizers on sodium, calcium and magensium during--- 2009/2010

\begin{tabular}{|c|c|c|c|c|c|c|}
\hline \multirow{2}{*}{ Treatments } & \multicolumn{2}{|c|}{ Sodium } & \multicolumn{2}{c|}{ Calcium } & \multicolumn{2}{c|}{ Magensium } \\
\cline { 2 - 7 } & \multicolumn{2}{|c|}{ No. of Cuts } & \multicolumn{2}{c|}{ No. of Cuts } & \multicolumn{2}{c|}{ No. of Cuts } \\
\cline { 2 - 7 } & 1 & 8 & 1 & 8 & 1 & 11.33 \\
\hline Urea (U) & 28.09 & 11.57 & 6.67 & 8.00 & 8.00 & 10.67 \\
\hline Farmyard Manure (FYM) & 24.32 & 10.40 & 7.33 & 8.67 & 6.00 & 14.33 \\
\hline Chicken Manure (CHM) & 28.45 & 9.63 & 8.00 & 8.00 & 8.00 & 15.00 \\
\hline U+FYM & 28.32 & 9.97 & 7.67 & 7.67 & 8.00 & 15.33 \\
\hline U+CHM & 36.76 & 11.67 & 8.00 & 8.33 & 10.00 & 13.33 \\
\hline FYM+CHM & 31.60 & 8.77 & 8.33 & 10.33 & 9.00 & 13.33 \\
\hline U+FYM+CHM & 32.46 & 10.27 & 9.33 & 10.00 & 7.00 & 16.67 \\
\hline Control & 30.12 & 10.47 & 6.33 & 10.00 & 6.00 & 4.05 \\
\hline LSD 5\% & 10.74 & 3.83 & 2.28 & 2.98 & 2.19 & 29.55 \\
\hline C.V & 20.43 & 21.15 & 16.87 & 19.14 & 12.33 & 2.31 \\
\hline SE \pm & 6.13 & 2.19 & 1.30 & 1.70 & 3.84 & 2 \\
\hline
\end{tabular}

$\mathrm{U}=$ Urea. $\mathrm{FYM}=$ Farmyard Manure. $\mathrm{CHM}=$ Chicken Manure. $\mathrm{LSD}=$ Least Significant Difference. $\mathrm{CV} \%=$ Coefficient of Variation. $\mathrm{SE} \pm=\mathrm{Standard}$ Error.

[3] Adam, M.Y. (2004). Effect of Seed Rate and Nitrogen on Growth and Yield of Teff Grass (Eragrostis teff zucc.) Trotter. M.Sc. Thesis. Faculty of Agriculture, University of Khartoum, Sudan.

\section{REFERENCES}

[1] Abbass, N.B. (2003). Response of Grasses and Legumes in Mixtures and Pure Stand to Phosphorus and Nitrogen Fertilization at ElDamazain Area. M.Sc. Thesis. Faculty of Agriculture, University of Khartoum, Sudan.

[2] Adam, H.S. (1996). The Agriculture Climate. Dar Alassala Publication. $1^{\text {st }}$ ed. P57 (Arabic).
[4] A.O. A.C. 1984. Officials methods of Analysis. Assoiciation of official Analytical chemists. Wshington. D.C., USA.

[5] Brima, F.I.A. (2007). Effect of Seed Rate and NPK Fertilization on Growth, Yield and Forage Quality of Rhodes grass (Chloris gayana L. Kunth). M.Sc. Thesis. Faculty of Agriculture, University of Khartoum, Sudan. 
[6] El Basari, A.M. (1999). Effect of Natural Amendments and Aggregates Stability and Water Flow in Different Soils. M.Sc. Thesis. Faculty of Agriculture, University of Khartoum, Sudan.

[7] Eltelib, H.A.M. (2004). Effect of Time of N Application on Growth and Yield and Quality of Four Forage Sorghum Cultivars. M.Sc. Thesis. Faculty of Agriculture, University of Khartoum, Sudan.

[8] Gasim, S.A. (2001) Effect of Nitrogen, Phosphorus and Seed Rate on Growth, Yield and Quality of Forage Maize (Zea mays L.). M.Sc. Thesis. Faculty of Agriculture, University of Khartoum, Sudan.

[9] Hassan, E.A.H. (2002). Effect of Chicken Manure and Season on the Performanceand HCN Content of two Forage Sorghum Cultivars. Ph.D. Thesis. Faculty of Agriculture, University of Khartoum, Sudan.

[10] Keftasa, D. (1990). Effect of Management Practices on Rhodes Grass and Lucerne Pasture with Especial References to Development Stage at Cutting and Associated Change in Nutritional Quality. Institute of Agriculture Research, Kulumsa Research Center, Ethiopia.
[11] Mohammed, H.M. (2000). Pasture in Sudan ways of support and development. Paper presented in the conference for the role of ranchers in the development of pastoral sector. Jeddah, Saudi Arabia. (In Arabic). Cited by Adam, M.Y. (2004).

[12] M STAT-C.(1989). Micro computer statistical program for experimental design, data management and data analysis. Version 2.10. (Institute of International Agriculture, Michigan State University, Soil and Crop Science, and Agriculture Ecnomics). U.S.A.

[13] Reed, C.F. (1976). Information Summarizes on 1000 Economic Plant. Typescripts Submitted to the USDA.

[14] Saad, H.H. (2009). Evaluation of Nitrogen Fertilizers on Quality and Quantity of Rhodes Grass (Chloris gayana L. Kunth). M.Sc. Thesis. Faculty of Agriculture Studies, Sudan University of Science and Technology, Sudan.

[15] Soliman, A.M. (2005). Evaluation of some Teosinte (Euchlaena Mexicana schard.) genotype of forage yield as affected by cutting management and nitrogen fertilization. Zagazig Journal of Agriculture Research.Volume 32(1) : 717-737. 